\title{
Return on equity: A popular, but flawed measure of corporate financial performance
}

\author{
J.H.v.H. de Wet* and E. du Toit \\ Department of Financial Management, University of Pretoria \\ Lynnwood Road, Hillcrest, Pretoria 0002, Republic of South Africa \\ johannes.dewet@up.ac.za
}

Received October 2006

\begin{abstract}
This article is aimed at analysing the impact of popular financial performance measures on shareholders' wealth. It tests the strength of the linear relationships between these performance measures and shareholders' returns, which consist of dividends and changes in the share price. The return on equity (ROE) is weighed up against the present favourite, economic value added (EVA) and the merits and flaws of each approach are discussed. Other approaches, such as a combination of performance measures and the expectations theory are also discussed briefly.
\end{abstract}

The statistical tests performed found Spreads (a standardised EVA) to be slightly superior to ROE in explaining changes in shareholders' returns. However, the use of same year data resulted in very weak linear relationships between all the performance measures tested, relative to shareholders' returns.

When 5-year medians were used in the analysis, significant correlations were obtained between current shareholders' returns and the future results for the internal performance measures. This engenders some support for the expectations theory with its contention that the most effective positive impact on shareholders' returns can be accomplished by managing expectations about future financial results, rather than maximising these results now. It is clear that the debate about the effectiveness of traditional accounting performance measures, as well as the search for the real drivers of shareholder value, will continue and increase in intensity.

*To whom all correspondence should be addressed.

\section{Introduction}

The ultimate purpose for any profit-seeking organisation is to create wealth for its owners. It is the goal of a street vendor, as well as for a large listed company. The only difference is that the street vendor operates for the benefit of one person whereas a listed company operates for the benefit of a large number of shareholders. According to Black, Wright and Davies (2001:9) shareholder value is created when the equity returns of a company exceed the cost of that equity. It can also be described as the present value of all future cash flows, less the cost of debt.

Reimann (1989:2) states that shareholder interests have been recognised as important for a long time, but that performance measures rarely show that this objective is achieved. He argues that it is so because managers often do not know how to do it. Muehlhauser (1995:47) recognises that selecting, managing and communicating results are as important as choosing strategies. The process of determining whether objectives are met, rather than setting the objectives, makes creating shareholder value one of the most difficult management tasks.

There is still some controversy regarding the measurement of shareholder value. The controversy is not about measuring shareholder value itself, but about identifying and measuring the internal driver(s) of performance that have the greatest impact on shareholder value. Numerous authors like Finegan (1991:36), Stern (1993:36), O’Byrne (1996:119), Uyemura, Kantor and Pettit (1996:98), Dodd and Chen (1996:27), Milunovich and Tsuei (1996:111), Kramer and Pushner (1997:41), Makelainen (1998:15) and Biddle, Bowen and Wallace (1999:69) have researched the impact of internal drivers on shareholder value. The approach used by all these researchers was to test the correlation between a measure of shareholder value (e.g. shareholder returns) and a chosen internal performance measure (e.g. earnings per share).

Over the years a number of performance measures have been used on the assumption of having some correlation with shareholder value. Financial managers, analysts and researchers have been of the opinion that the value of a company can be determined by using traditional accounting measures of performance like earnings per share, return on assets and dividends per share. However, Black et al. (2001:10) revealed findings by economists that showed little correlation between historical accounting returns and stock market performance.

This study limits itself to focusing on the return on equity (ROE) as the most popular accounting measure of performance and then also discusses the current favourite, namely economic value added (EVA), as well as the use of a 
combination of performance measures (a balanced metric) and expectations theory as possible alternatives.

\section{Literature review}

\section{Return on equity (ROE)}

ROE, along with return on assets (ROA), is one of the alltime favourites and perhaps most widely used overall measure of corporate financial performance (Rappaport 1986:31). This was confirmed by Monteiro (2006:3) who stated that ROE is perhaps the most important ratio an investor should consider. The fact that ROE represents the end result of structured financial ratio analysis, also called Du Pont analysis (Stowe, Robinson, Pinto \& McLeavy, 2002:85; Correia, Flynn, Uliana \& Wormald, 2003:5-19; Firer, Ross, Westerfield \& Jordan, 2004:67) contributes towards its popularity among analysts, financial managers and shareholders alike.

Appendix A contains a diagram showing how ROE can be analysed further and broken down into other well-known financial accounting ratios. These ratios cover the categories of profitability, asset management and financial structure. Instead of regarding ROE as the point of departure, one could also view it as the final result of structured financial ratio analysis (Firer et al., 2004:68).

ROE is calculated by taking the profit after tax and preference dividends of a given year and dividing it by the book value of equity (ordinary shares) at the beginning of the year. Average equity can also be used. Equity would consist of issued ordinary share capital, plus the share premium and reserves.

The calculation of ROE can be broken up into three separate ratios, as follows:

$$
\text { ROE }=\frac{\text { Earnings }}{\text { Sales }} \times \frac{\text { Sales }}{\text { Assets }} \times \frac{\text { Assets }}{\text { Equity }}
$$

The three components, or ratios, can be described (in sequence) as profitability, asset turnover and financial leverage. The ROE can therefore be improved by improving profitability, by using assets more efficiently and by increasing financial leverage. Over time it has become clear that improving the ROE may not necessarily improve shareholder value.

Although ROE has some appeal because it links the income statement (earnings) to the balance sheet (equity), it has some serious flaws as a measure of performance. The first and most obvious flaw is that the earnings can be (and is) manipulated legally within the framework of Generally Accepted Accounting Practice (GAAP) via changes in accounting policy. The second flaw is that ROE is calculated after the cost of debt, but before taking into account the cost of own capital. ROE increases with more financial gearing, as long as the returns earned on the borrowed funds exceed the cost of the borrowings. The danger inherent in increasing the financial gearing beyond a certain level is that the increased financial risk may cause the value of the company and the share price to fall.
Pursuing a higher ROE may lead to wealth destruction, which is not in line with the economic principles of shareholder value creation.

Rappaport (1986:43) has pointed out that the second component of ROE, namely asset turnover, is affected by inflation in such a way that it may increase even when assets are not utilised better. He reasons that sales immediately reflect the impact of inflation, whereas the book value of assets, which is a mixture of new and older assets, does not adapt as quickly to the effects of inflation.

Rappaport's (1986:43) studies in the 1970's revealed that although the earnings of Standard \& Poor's 400 companies decreased dramatically during the 1970's, their ROEs actually increased through increased levels of asset turnover and gearing. The markets, however, were not misled by this apparent 'better performance'. Consequently the market returns during this period were generally very poor, or 'dismal', according to Rappaport.

Around 1989 when Reimann (1989:3) published his work, ROE was used extensively for measuring whether value was being created for shareholders. The reason behind the adoption of ROE as a measure was that it gave more reliable results than earnings per share (EPS) (Reimann, 1989:18). As it is important to consider how investors value the shares of a company Reimann (1989:7) considered a number of strategy consulting firms and found that they focus their measurements on the spread between ROE and the cost of equity. If the spread is positive, it indicates that a company has advantageous growth opportunities.

Reimann (1989:8) also identified changes to accounting conventions (policies) as being a problem when using ROE as a performance measure. It was also recognised that financial measures such as ROE may be too short-term and that longer-term measures, perhaps more qualitative, must be adopted as well. Reimann (1989:18) found that ROE still left 66 percent of the variation in share prices unexplained, indicating a large degree of unreliability.

Another problem with the use of ROE, as identified by Finegan (1991:33) is that it does not consider the timing of cash flows. For that reason the free cash flow model is often cited as a better means to determine whether shareholder value is being created. Finegan (1991:45) also stated that investors 'go far beyond earnings in evaluating performance'. Therefore the managers of a company cannot rely on earnings figures alone to measure performance, unless they want to wait for investors' reactions to see how they are performing.

Copeland, Koller and Murrin (1996:105) argue that ROE is a short-term performance measure and that too much focus on it can lead a company to overlook long-term growth opportunities that might increase shareholder value. A company may also be able to improve its ROE, while at the same time earning a return that is below its weighted average cost of capital (WACC), and thereby destroy value. 


\section{Return on equity (ROE) versus economic value added (EVA)}

Jensen and Meckling (1999:13) claim that, even though many companies use ROE, it is susceptible to manipulation when managers have rights to make decisions over the level of investment. They recognise the use of EVA, but clearly indicate that it is also not the best measure. This is because projects with negative EVA in early years will not be chosen if managers are evaluated on current EVA figures, even though the future annual EVA is enough to justify the investment.

At this point, it may be advisable to briefly review the definition of EVA. EVA is the economic profit of a company, after taking into account the full cost of capital. It is determined as follows:

EVA $=($ ROIC - WACC $) \times$ IC

where

ROIC $=$ Return on invested capital

WACC $=$ Weighted average cost of capital

IC = Invested capital (at the beginning of the year)

EVA can also be determined by subtracting the cost of equity from the earnings:

EVA $=$ Earnings $-\left(k_{\mathrm{e}} \mathrm{x}\right.$ equity $)$

where

$\mathrm{k}_{\mathrm{e}} \quad=$ Cost of equity

Today, ROE is still used extensively for measuring company performance. However, Black et al. (2001:50) found that it is not consistent with the creation of shareholder value. The main disadvantage of ROE is that it is affected by a company's gearing levels. Gearing and asset turnover can influence the ROE so that higher gearing and higher asset turnover, which are not necessarily beneficial, can cause ROE to be higher. The example in Table 1 illustrates how ROE can be increased by increasing debt, even if the company is destroying value.

The movement of the WACC at the different levels of financial gearing $(0 \%, 20 \%, 40 \%, 60 \%$ and $80 \%$ of net assets) is in line with the contemporary approach of Miller and Modigliani's theory on capital structure (Hawawini \& Viallet, 1999:362). The model shows how ROE can be increased by using more debt relative to equity, even at very high levels of debt. In contrast, the EVA is highest at a moderate level of long term debt ( $40 \%$ of assets) and, not surprisingly, it is also at this financial structure where the
WACC is lowest (and the value of the firm would be highest).

Thomas and Lipson, as cited by Black et al. (2001:53), found through their research as far back as the 1980s that the coefficient of determination $\left(\mathrm{r}^{2}\right)$ of ROE to market/book ratios was 19 percent, which indicated that changes in market to book ratios cannot be reliably explained by ROE. However, Black et al. (2001:257) found that ROE was still a key measure, as the concept of shareholder value reinforces the message that returns on invested capital (equity) must be improved and cost of capital must be reduced.

Black et al. (2001:299) reported that even though some Japanese companies have realised the shortcomings of using ROE to measure shareholder wealth, most still believe that ROE is the best indicator of shareholder value. One company that does not believe in the use of ROE is the Japanese firm 'Hoya'. They adapted EVA to suit their specific needs and calls it shareholder value added (SVA). However, they do believe that maximising SVA on the long run will also increase ROE. Their opinion is that their SVA measure and ROE are not contradictory, but rather complementary.

Stewart III (2003:63) from Stern Stewart \& Co claims that the main cause for problems in value measurement lies therein that accounting has become "unhinged" from value. Accounting has become a tool to make earnings reports look better. It has the effect that accounting measures cannot be relied upon for value measurement. Another problem that Stewart III (2003:66) identifies is specifically related to the use of ROE for measuring value. ROE ignores the cost of equity while equity is not a free resource and has a cost the same as the interest charged on debt. That leads to companies often reporting profits while they are really not creating value or even destroying value. That is why the concept of economic profit or residual value is seen to be a better measure. Its calculation is as follows:

Economic profit $=$ Accounting profit - Cost of equity .

An example of a firm that concentrated its focus on earnings and ROE is Enron (Stewart III, 2003:68). The management of Enron were apparently so focused on earnings per share (EPS) and ROE that they started to use debt to a large extent. Leverage increased remarkably, but still the managers did not want to tap into equity markets to relieve financial stress, afraid that it will have an adverse impact on earnings figures. However, positive earnings figures did not create value for shareholders and did not prevent the company from going down.

Table 2 presents a summary of some research results over the period 1991 to 1999 regarding the relationship between different internal performance measures (EVA, ROE and EPS) and market value. 'N/A' was used to indicate that the relevant information was not available. 
Table 1: ROE versus EVA at different levels of financial gearing

\section{ASSUMPTIONS:}

Fixed assets + net working capital

$$
R \text { million } \quad R \text { million } \quad R \text { million } \quad R \text { million } \quad R \text { million }
$$

Equity

Long-term debt

\begin{tabular}{lllll}
\hline 1000 & 1000 & 1000 & 1000 & 1000 \\
\hline \hline
\end{tabular}

\begin{tabular}{rrrrr}
1000 & 800 & 600 & 400 & 200 \\
0 & 200 & 400 & 600 & 800 \\
\hline 1000 & 1000 & 1000 & 1000 & 1000 \\
\hline \hline
\end{tabular}

Tax rate

Interest (before tax)

\begin{tabular}{|c|c|c|c|c|}
\hline $29,0 \%$ & $29,0 \%$ & $29,0 \%$ & $29,0 \%$ & $29,0 \%$ \\
\hline N/A & $10,0 \%$ & $15,0 \%$ & $20,0 \%$ & $25,0 \%$ \\
\hline N/A & $7,1 \%$ & $10,7 \%$ & $14,2 \%$ & $17,8 \%$ \\
\hline $20,0 \%$ & $22,0 \%$ & $24,0 \%$ & $26,0 \%$ & $28,0 \%$ \\
\hline
\end{tabular}

Interest (after tax)

$20,0 \%$

WACC (note 4)

Ranking i.t.o. WACC (lowest percentage is best)

$20,0 \%$

$19,0 \%$

$18,7 \%$

$18,9 \%$

$19,8 \%$

$5 \quad 3$

$40,0 \%$

$40,0 \%$

$40,0 \%$

$40,0 \%$

$40,0 \%$

Earnings before interest and tax as a \% of assets

\section{CALCULATIONS:}

Earnings before interest and tax (EBIT)

\begin{tabular}{rrrrr}
$R$ million & $R$ million & $R$ million & $R$ million & $R$ million \\
400 & 400 & 400 & 400 & 400 \\
0 & 20 & 60 & 120 & 200 \\
\hline 400 & 380 & 340 & 280 & 200 \\
116 & 110 & 99 & 81 & 58 \\
\hline 284 & 270 & 241 & 199 & 142 \\
\hline \hline
\end{tabular}

Interest

Earnings before tax (EBT)

Tax

Earnings after tax (EAT)

ROE (note 5)

Ranking i.t.o. ROE (highest percentage is best)

EVA (note 6)

Ranking i.t.o. EVA (highest amount is best)

$\begin{array}{rrrrr}28,4 \% & 33,7 \% & 40,2 \% & 49,7 \% & 71,0 \% \\ 5 & 4 & 3 & 2 & 1 \\ 84 & 94 & 97 & 95 & 86 \\ 5 & 3 & \mathbf{1} & 2 & 4\end{array}$

(Consistent with WACC ranking)

Alternative calculation for EVA:

ROIC (note 7)

\begin{tabular}{rrrrr}
$28,4 \%$ & $28,4 \%$ & $28,4 \%$ & $28,4 \%$ & $28,4 \%$ \\
$20,0 \%$ & $19,0 \%$ & $18,7 \%$ & $18,9 \%$ & $19,8 \%$ \\
$8,4 \%$ & $9,4 \%$ & $9,7 \%$ & $9,5 \%$ & $8,6 \%$ \\
1000 & 1000 & 1000 & 1000 & 1000 \\
\hline 84 & 94 & 97 & 95 & 86 \\
\hline \hline
\end{tabular}

WACC

Spreads

Invested capital

EVA

Notes:

1. All amounts are rounded to the nearest $\mathrm{R}$ million.

2. All percentages are rounded to 0,1 of a percentage.

3. $\mathrm{t}=$ company income tax rate.

4. WACC $=$ equity/assets $x$ cost of equity + debt/assets $x$ cost of debt.

5. $\mathrm{ROE}=$ EAT / Equity.

6. $\mathrm{EVA}=\mathrm{EAT}-$ (cost of equity $\% \mathrm{x}$ equity $)$.

7. ROIC $=\operatorname{EBIT} x(1-t) /$ assets. 
Table 2: Regression of market value and EVA, ROE and EPS

\begin{tabular}{c|l|c|c|c|c}
\hline Year & \multicolumn{1}{|c|}{ Researchers } & $\begin{array}{c}\text { Market value } \\
\text { indicator }\end{array}$ & $\begin{array}{c}\mathbf{r}^{2} \text { with } \\
\text { EVA }\end{array}$ & $\begin{array}{c}\mathbf{r}^{2} \text { with } \\
\text { ROE }\end{array}$ & $\begin{array}{c}\mathbf{r}^{2} \text { with } \\
\text { EPS }\end{array}$ \\
\hline 1991 & Finegan & MVA & $61 \%$ & N/A & $10 \%$ \\
\hline 1993 & Stern & MVA & $50 \%$ & $25 \%$ & $18 \%$ \\
\hline 1996 & Uyemura et al. & MVA & $40 \%$ & $10 \%$ & $6 \%$ \\
\hline 1996 & Dodd \& Chen & Share returns & $20 \%$ & $6 \%$ & $6 \%$ \\
\hline 1996 & Milunovich \& Tsuei & MVA & $42 \%$ & $29 \%$ & $34 \%$ \\
\hline 1999 & Biddle et al. & Share returns & $6 \%$ & N/A & N/A \\
\hline 'AVERAGE' & & $37 \%$ & $\mathbf{1 8 \%}$ & $\mathbf{1 5 \%}$ \\
\hline
\end{tabular}

The results shown in Table 2 indicate that after strong initial correlation found between market value and EVA, the $\mathrm{r}^{2}$ generally decreased for studies subsequent to 1991 . Although not scientifically correct, the 'average' $r^{2}$ of $37 \%$ shows that a large part of the variation in market value cannot be explained by changes in the EVA of a company. The 'average' $r^{2}$ of $18 \%$ for ROE and 15\% for EPS supports the contention that, in spite of its popularity, these accounting indicators are inappropriate as performance measures of shareholder wealth.

Copeland (2002:52) found 'little or no correlation between short-term total return to shareholders and short-term earnings per share, growth in earnings, economic value added, or the change in present economic value added'. A study by De Wet (2004:241) on companies listed on the Johannesburg Securities Exchange South Africa, found very low correlation between EVA and MVA on a year-on-year basis $\left(r^{2}\right.$ of $\left.4,5 \%\right)$.

The conclusion from the theoretical survey is that, in spite of their widespread appeal and application, neither ROE nor EVA can be seen as reliable performance measures that can be maximised in order to maximise shareholder value.

\section{Possible alternatives}

\section{A combination of performance measures}

Traditionally, all business measurements have been financial and this practice has been criticised by many commentators (Kaplan \& Norton, 1996:22). However, as Black et al. (2001:329) recognise that there may still be a place for financial measures such as ROE and various others in what they call a 'metrics scorecard'. It involves the use of a variety of performance measures (financial and nonfinancial) to achieve certain goals.

The use of multiple measures is best done through a balanced scorecard, which takes various aspects of a business and adds it together in one model to achieve certain strategic goals. It emphasises the fact that financial and nonfinancial information must be considered together for all decisions and actions.

In each of the perspectives of the balanced scorecard, relevant measures need to be established. Kaplan and Norton (1996:182) recognise the importance of looking at maximising shareholder value through the objectives and measures in the financial perspective. Therefore, valuemaximising measures such as ROE and EVA are recommended. However, the preferred measurement method depends on the specific needs of the organisation.

\section{Expectations theory}

Copeland (2002:48) states that research by 'Monitor Corporate Finance' indicated that financial metrics such as earnings, earnings per share growth and EVA do not correlate with the total return to shareholders. He believes that market expectations are a better measure of shareholder value. Expectation-based management uses the difference between actual and expected performance as a measure linked to the total return to shareholders.

Copeland (2002:48) did a survey on data from the S\&P 500 companies from 1992 to 1998 and found little correlation between their short-term total return to shareholders and their short-term EPS, growth in earnings, EVA, and their percentage change in EVA. However, he found a highly significant correlation between the total return to shareholders and analysts' expectations of earnings. This expectations-based measure (expected earnings) showed an $r^{2}$ of $42 \%$ relative to the total shareholders' return.

Copeland (2002:51) argues that a business unit that earns more than its cost of capital and thus has a positive EVA, only creates value (market value) if it earns more than expected. So, for example, if a company has a WACC of $15 \%$ and it is expected to earn $30 \%$ but actually earns $25 \%$, it under-performs in terms of the expectations and therefore destroys value. The reason for this is that the expectation of a $30 \%$ return has already been discounted into the current share price.

\section{Research questions}

The most imminent question to be asked is what impact internal measures of corporate performance, like ROE and EVA, have on shareholder returns, individually and in conjunction with other well-known financial accounting ratios. Furthermore, it is important to know whether one performance measure is superior to the other, especially in the South African business environment. The role and impact of other popular performance measures on shareholder returns need also be investigated and reported.

\section{Research method}

The source of the information used in the study was the McGregor BFA at the University of Pretoria. As a first step, 
a decision was made to use all the companies listed on the JSE on 30 April 2006, a total of 340.

Next, it was decided that for the purposes of this study industrial companies would provide the required information to determine the critical variables for the analysis. There were 175 industrial companies listed.

The next criterion was the availability of data. In order to have complete, calculated data for the ten-year period from 1996 to 2005, the raw data on each company had to be available for the full eleven-year period from 1995 to 2005 for each company. After the elimination of companies with incomplete data, 83 remained.

In determining the external measure of performance, shareholder returns, the ordinary dividend per share for a given year plus the change in the market price per share were added together to give the return for the year. This return was then divided by the market price per share at the beginning of the year to yield the shareholder return for the year. The different internal performance measures to be used for regression analyses were:

- $\quad$ the return on equity, or ROE;

- the performance spread, or 'Spread', which is a standardised EVA (EVA/IC $\mathrm{Ceg}_{\text {eg }}$;

- $\quad$ the earnings per share, or EPS;

- $\quad$ the ordinary dividends per share, or DPS;

- $\quad$ interest bearing debt / total assets; and

- the cash flow from operations (after tax, but before interest and dividends) standardised as $\mathrm{CFL} / \mathrm{IC}_{\mathrm{beg}}$.

The regression analyses were done by including each of the six independent variables mentioned above relative to the shareholder returns (dependent variable) over the ten-year period from 1996 to 2005, on a year-on-year basis. The ROIC (required to determine the EVA) was calculated by dividing the net operating profit after tax (NOPAT) by the IC at the beginning of the year and expressing it as a percentage. NOPAT is calculated by taking EBIT (without investment income) and multiplying it with (1 - tax rate).

The WACC was determined by using appropriate weights (in terms of market value) for each component of long-term capital. A risk-free rate, the market premium and a betafactor were used in the capital asset pricing model (CAPM) to calculate the cost of equity. The government bond R150 was used as a proxy for the risk-free rate and an estimated $6 \%$ was used as the market premium. The beta-factor was automatically calculated by the BFA database system. For the other components of long-term capital, such as longterm loans, the appropriate after-tax cost was used.

The Spread, also called the 'return spread', was determined by subtracting the WACC from the ROIC. The EVA was calculated by multiplying the Spread with the IC. The EVA was determined for a given year and was expressed as an amount in Rand.

\section{Research results}

In order to determine the impact of the performance measures as specified on the shareholder returns, a number of linear regressions were performed. As a first step, simple linear regression was done with shareholder returns relative to one independent variable (e.g. ROE) at a time. The data used was year-on-year, meaning that the shareholder returns for a given company during the year 2005 were correlated with the ROE, or other independent variable for 2005. The results of the simple linear regressions are contained in Table 3.

Table 3: Simple linear regression of shareholders' returns with each independent variable using year-onyear data

\begin{tabular}{l|c}
\hline \multicolumn{1}{c|}{ Variable } & $\mathbf{r}^{2}$ \\
\hline ROE & $0,90 \%$ \\
\hline Spreads & $3,80 \%$ \\
\hline EPS & $0,70 \%$ \\
\hline DPS & $11,70 \%$ \\
\hline Debt/Assets & $0,00 \%$ \\
\hline CF/IC & $0,00 \%$ \\
\hline
\end{tabular}

The results in Table 3 show weak correlations between shareholders' returns and all the independent variables, using year-on-year data. The strongest linear relationship was found between shareholder returns and dividends per share (reflected by an $\mathrm{r}^{2}$ of 0,117 ), but this was to be expected because the dividend per share formed an integral part of the shareholder returns. Notably, the relationship between shareholder returns and ROE was almost nonexistent $\left(r^{2}\right.$ of 0,009$)$, with Spreads $\left(r^{2}\right.$ of 0,038$)$ only slightly better, but hardly significant.

As a next step, two stepwise linear regressions were performed, using year-on-year data. In the first stepwise regression, shareholder returns were taken as the dependent variable and ROE, EPS, DPS, interest bearing debt divided by assets and cash flow from operations were taken as independent variables. The results of this stepwise regression are shown in Table 4.

The results show an $r^{2}$ of 0,145 after the third and final step of the regression, indicating that changes in the independent variables only contribute to $14,5 \%$ of the changes in shareholders' returns. It is interesting to note that the ROE did not even feature in the final list of independent variables making a significant contribution towards the strength of the relationship with shareholders' returns.

The second stepwise regression was done using shareholder returns as the dependent variable and Spreads as well as EPS, DPS, interest bearing debt divided by assets and cash flow from operations as independent variables. The results of this stepwise regression are shown in Table 5. 
Table 4: Stepwise regression of shareholders' returns with ROE and other independent variables, excluding Spreads

\begin{tabular}{|c|c|c|c|}
\hline \multicolumn{4}{|c|}{ Step 1: Summary } \\
\hline$R^{2}$ & $R$ & Adj. $R^{2}$ & S.E. of Estimate \\
\hline 0,117 & 0,342 & 0,116 & 97,990 \\
\hline
\end{tabular}

\begin{tabular}{|l|c|r|r|r|r|}
\hline \multicolumn{1}{|c|}{ Step 1: ANOVA } \\
\hline \multicolumn{1}{|c|}{ Source } & \multicolumn{1}{|c|}{ Sum Sq. } & D.F. & Mean Sq. & F & Prob. \\
\hline Regression & 1053725,455 & 1 & 1053725,455 & 109,739 & 0,000 \\
\hline Residual & 7950566,662 & 828 & 9602,134 & & \\
\hline Total & 9004292,117 & 829 & & & \\
\hline
\end{tabular}

\begin{tabular}{|l|r|r|r|r|r|r|r|}
\hline \multicolumn{1}{|l|}{ Step 1: Regression Coefficients } \\
\hline \multicolumn{1}{|c|}{ Source } & Coefficient & Std Error & Std Beta & -95\% C.I. & \multicolumn{1}{c|}{$+95 \%$ C.I. } & \multicolumn{1}{c|}{ Prob. } \\
\hline Intercept & 16,147 & 3,654 & & 8,974 & 23,320 & 4,419 & 0,000 \\
\hline DPS & 0,153 & 0,015 & 0,342 & 0,124 & 0,181 & 10,476 & 0,000 \\
\hline
\end{tabular}

\begin{tabular}{|c|c|c|c|}
\hline \multicolumn{4}{|c|}{ Step 2: Summary } \\
\hline$R^{2}$ & $R$ & Adj. $R^{2}$ & S.E. of Estimate \\
\hline 0,138 & 0,372 & 0,136 & 96,860 \\
\hline
\end{tabular}

\begin{tabular}{|l|c|r|r|r|r|}
\hline \multicolumn{7}{|c|}{ Step 2: ANOVA } \\
\hline \multicolumn{1}{|c|}{ Source } & \multicolumn{1}{|c|}{ Sum Sq. } & D.F. & Mean Sq. & F & Prob. \\
\hline Regression & 1245437,388 & 2 & 622718,694 & 66,374 & 0,000 \\
\hline Residual & 7758854,729 & 827 & 9381,928 & & \\
\hline Total & 9004292,117 & 829 & & & \\
\hline
\end{tabular}

\begin{tabular}{|l|r|r|r|r|r|r|r|}
\hline \multicolumn{1}{|l|}{ Step 2: Regression Coefficients } \\
\hline \multicolumn{1}{|c|}{ Source } & Coefficient & Std Error & Std Beta & $-95 \%$ C.I. & \multicolumn{1}{c|}{$+95 \%$ C.I. } & $t$ & Prob. \\
\hline Intercept & 22,125 & 3,847 & & 14,575 & 29,676 & 5,752 & 0,000 \\
\hline EPS & $-0,056$ & 0,012 & $-0,180$ & $-0,080$ & $-0,031$ & $-4,520$ & 0,000 \\
\hline DPS & 0,200 & 0,018 & 0,448 & 0,165 & 0,235 & 11,235 & 0,000 \\
\hline
\end{tabular}

\begin{tabular}{|c|c|c|c|}
\hline \multicolumn{4}{|c|}{ Step 3: Summary } \\
\hline$R^{2}$ & $R$ & Adj. $R^{2}$ & S.E. of Estimate \\
\hline 0,145 & 0,381 & 0,142 & 96,547 \\
\hline
\end{tabular}

\begin{tabular}{|c|c|c|c|c|c|}
\hline \multicolumn{6}{|c|}{ Step 3: ANOVA } \\
\hline Source & Sum Sq. & D.F. & Mean Sq. & $F$ & Prob. \\
\hline Regression & 1304872,900 & 3 & 434957,633 & 46,663 & 0,000 \\
\hline Residual & 7699419,218 & 826 & 9321,331 & & \\
\hline Total & 9004292,117 & 829 & & & \\
\hline
\end{tabular}

\begin{tabular}{|l|r|r|r|r|r|r|r|}
\hline \multicolumn{1}{|l|}{ Step 3: Regression Coefficients } \\
\hline \multicolumn{1}{|c|}{ Source } & Coefficient & Std Error & Std Beta & $-95 \%$ C.I. & \multicolumn{1}{l|}{$+95 \%$ C.I. } & \multicolumn{1}{c|}{$t$} & Prob. \\
\hline Intercept & 19,336 & 3,990 & & 11,504 & 27,169 & 4,846 & 0,000 \\
\hline EPS & $-0,060$ & 0,012 & $-0,194$ & $-0,084$ & $-0,036$ & $-4,837$ & 0,000 \\
\hline DPS & 0,208 & 0,018 & 0,466 & 0,173 & 0,244 & 11,544 & 0,000 \\
\hline Cfo/IC & 0,226 & 0,090 & 0,083 & 0,050 & 0,402 & 2,525 & 0,012 \\
\hline
\end{tabular}


Table 5: Stepwise regression of shareholders' returns with Spreads and other independent variables, excluding ROE

\begin{tabular}{|c|c|c|c|}
\hline \multicolumn{4}{|c|}{ Step 1: Summary } \\
\hline$R^{2}$ & $R$ & Adj. $R^{2}$ & S.E. of Estimate \\
\hline 0,117 & 0,342 & 0,116 & 97,990 \\
\hline
\end{tabular}

\begin{tabular}{|l|c|r|r|r|r|}
\hline \multicolumn{7}{|l|}{ Step 1: ANOVA } & \multicolumn{1}{|c|}{ Source } & \multicolumn{1}{|c|}{ Sum Sq. } & D.F. & Mean Sq. & F & Prob. \\
\hline Regression & 1053725,455 & 1 & 1053725,455 & 109,739 & 0,000 \\
\hline Residual & 7950566,662 & 828 & 9602,134 & & \\
\hline Total & 9004292,117 & 829 & & & \\
\hline
\end{tabular}

\begin{tabular}{|l|r|r|r|r|r|r|r|}
\hline \multicolumn{1}{|l|}{ Step 1: Regression Coefficients } \\
\hline \multicolumn{1}{|c|}{ Source } & Coefficient & Std Error & Std Beta & -95\% C.I. & +95\% C.I. & $t$ & Prob. \\
\hline Intercept & 16,147 & 3,654 & & 8,974 & 23,320 & 4,419 & 0,000 \\
\hline DPS & 0,153 & 0,015 & 0,342 & 0,124 & 0,181 & 10,476 & 0,000 \\
\hline
\end{tabular}

\begin{tabular}{|c|c|c|c|}
\hline \multicolumn{4}{|c|}{ Step 2: Summary } \\
\hline$R^{2}$ & $R$ & Adj. $R^{2}$ & S.E. of Estimate \\
\hline 0,138 & 0,372 & 0,136 & 96,860 \\
\hline
\end{tabular}

\begin{tabular}{|l|c|r|r|r|r|}
\hline \multicolumn{1}{|c|}{ Step 2: ANOVA } \\
\multicolumn{1}{|c|}{ Source } & \multicolumn{1}{c|}{ Sum Sq. } & \multicolumn{1}{c|}{ D.F. } & \multicolumn{1}{c|}{ Mean Sq. } & \multicolumn{1}{c|}{ F } & Prob. \\
\hline Regression & 1245437,388 & 2 & 622718,694 & 66,374 & 0,000 \\
\hline Residual & 7758854,729 & 827 & 9381,928 & & \\
\hline Total & 9004292,117 & 829 & & & \\
\hline
\end{tabular}

\begin{tabular}{|l|r|r|r|r|r|r|r|}
\hline \multicolumn{1}{|l|}{ Step 2: Regression Coefficients } \\
\hline \multicolumn{1}{|c|}{ Source } & Coefficient & Std Error & Std Beta & $-95 \%$ C.I. & \multicolumn{1}{l|}{$+95 \%$ C.I. } & \multicolumn{1}{c|}{ Prob. } \\
\hline Intercept & 22,125 & 3,847 & & 14,575 & 29,676 & 5,752 & 0,000 \\
\hline EPS & $-0,056$ & 0,012 & $-0,180$ & $-0,080$ & $-0,031$ & $-4,520$ & 0,000 \\
\hline DPS & 0,200 & 0,018 & 0,448 & 0,165 & 0,235 & 11,235 & 0,000 \\
\hline
\end{tabular}

\begin{tabular}{|c|c|c|c|}
\hline \multicolumn{4}{|c|}{ Step 3: Summary } \\
\hline$R^{2}$ & $R$ & Adj. $R^{2}$ & S.E. of Estimate \\
\hline 0,154 & 0,392 & 0,151 & 96,037 \\
\hline
\end{tabular}

\begin{tabular}{|l|c|r|r|r|r|}
\hline \multicolumn{1}{|c|}{ Step 3: ANOVA } \\
\hline \multicolumn{1}{|c|}{ Source } & \multicolumn{1}{|c|}{ Sum Sq. } & D.F. & Mean Sq. & F & Prob. \\
\hline Regression & 1386048,267 & 3 & 462016,089 & 50,094 & 0,000 \\
\hline Residual & 7618243,850 & 826 & 9223,056 & & \\
\hline Total & 9004292,117 & 829 & & & \\
\hline
\end{tabular}

\begin{tabular}{|l|r|r|r|r|r|r|r|}
\hline \multicolumn{1}{|c|}{ Step 3: Regression Coefficients } \\
\hline \multicolumn{1}{|c|}{ Source } & Coefficient & Std Error & Std Beta & -95\% C.I. & \multicolumn{1}{c|}{$+95 \%$ C.I. } & \multicolumn{1}{c|}{$t$} & \multicolumn{1}{c|}{ Prob. } \\
\hline Intercept & 20,438 & 3,838 & & 12,904 & 27,972 & 5,325 & 0,000 \\
\hline Spread & 0,493 & 0,126 & 0,128 & 0,245 & 0,741 & 3,905 & 0,000 \\
\hline EPS & $-0,056$ & 0,012 & $-0,181$ & $-0,080$ & $-0,032$ & $-4,569$ & 0,000 \\
\hline DPS & 0,188 & 0,018 & 0,421 & 0,153 & 0,223 & 10,500 & 0,000 \\
\hline
\end{tabular}


The results show an $r^{2}$ of 0,154 after the third and final step of the regression, implying that changes in the independent variables only contribute to $15,4 \%$ of the changes in shareholders' returns. The features of note regarding this regression are that the final result was slightly better than for the first stepwise regression and that Spreads were included on the final list of independent variables that affect the changes in shareholder returns most significantly.

Stepwise linear regression performed on 5-year medians of all the data yielded the following results:

- For same period medians, the independent variables selected based on significance, were ROE and DPS, with an $r^{2}$ of 0,149 .

- For lagged shareholders' returns (SHRs), based on the assumption SHR $=\mathrm{f}$ (future Spreads, ROEs, etc.) the independent variables selected were ROE and Spreads, with an $r^{2}$ of 0,194 .

- For lagged independent variables based on the assumption SHR = $\mathrm{f}$ (past Spreads, ROEs, etc.) the correlations were so weak that none of the independent variables were selected for inclusion in the final regression model.

\section{Conclusion}

From the results of the simple linear regressions it is clear that no performance measure display a significantly strong relationship with shareholder returns. The correlation between Spreads and shareholder returns was slightly better than that between ROE and shareholder returns, but the relationships were very weak in both instances. One can infer that there is a very weak relationship between the same-year values for ROE, Spreads and the other measures tested relative to shareholder value. Managing and maximising these measures would therefore not necessarily lead to higher shareholder returns in the same year. Shareholder returns seem to be driven largely by other external factors, or by internal performance expected later, or performed earlier (not in the same year).

Stepwise regressions performed on the effect of a combination of internal performance measures on shareholders' returns showed a more meaningful impact on shareholders' value. However, the effect of ROE on shareholders' returns again proved to be insignificant. Spreads, along with EPS and DPS, was a major contributor to the correlation $\left(\mathrm{r}^{2}\right.$ of 0,154$)$ found using stepwise regression relative to shareholders' returns. This result, combined with its strong theoretical justification, supports a view that Spreads is superior to ROE as a performance measure of shareholder wealth creation.

The regression results using 5-year medians and lagged data strengthened the growing support for the expectations theory on the grounds that there was a much stronger relationship between shareholders' returns and future performance than between shareholders' returns and past performance.
Finally, the results of this study can be summarised in reporting that there is just about no correlation between shareholders' returns and ROE on a year-on-year basis. Spreads, which is a standardised EVA, appear to be slightly superior to ROE in explaining changes in shareholder's wealth, but its contribution is still not really significant if year-on-year data is used. Some evidence was found that there is a stronger relationship between current shareholders' returns and the future data of performance measures like Spreads, EPS, DPS and ROE. This indicates that it may be more important to manage future expectations about these measures of internal performance than trying to maximise the measures themselves. The search for the real drivers of shareholders' wealth continues.

\section{References}

Biddle, G.C., Bowen, R.M. \& Wallace, J.S. 1999. 'Evidence on EVA', Journal of Applied Corporate Finance, 12(2):6979 .

Black, A., Wright, P. \& Davies, J. 2001. In search of shareholder value. $2^{\text {nd }}$ Edition. London: Pearson.

Copeland, T.E., Koller, T. \& Murrin, J. 1996. Valuation: measuring and managing the value of companies. $2^{\text {nd }}$ Edition. New York: Wiley \& Sons.

Copeland, T. 2002. 'Want to create value?', Strategic Finance. 83(9): 48-54.

Correia, C., Flynn, D., Uliana, E. \& Wormald, M. 2003. Financial management. $5^{\text {th }}$ Edition. Cape Town: Juta.

De Wet, J.H.vH. 2004. 'A strategic approach in managing shareholders' wealth for companies listed on the JSE securities exchange South Africa'. Doctoral thesis, University of Pretoria, Pretoria.

Dodd, J.L. \& Chen, S. 1996. 'EVA: A new panacea?', B \& E Review, July - September: 26-28.

Finegan, P.T. 1991. 'Maximising shareholder value at the private company', Journal of Applied Corporate Finance, 4(1):30-45.

Firer, C., Ross, S.A., Westerfield, R.W. \& Jordan, B.D. 2004. Fundamentals of corporate finance. $3^{\text {rd }}$ South African edition. New York: McGraw-Hill.

Hawawini, G. \& Viallet, C. 1999. Finance for executives. Cincinnati, Ohio: Thomson.

Jensen, M.C. \& Meckling, W.H. 1999. 'Specific knowledge and divisional performance measurement', Journal of Applied Corporate Finance, 12(2):8-17.

Kaplan, R.S. \& Norton, D.P. 1996. Translating strategy into action: the balanced scorecard. Boston: Harvard Business School. 
Kramer, J.K. \& Pushner, G. 1997. 'An empirical analysis of economic value added as a proxy for market value added', Financial Practice and Education, Spring/Summer: 41-49. Makelainen, E. 1998. 'Economic value added as a management tool'. [online] URL: http://www.evanomics.com/evastudy/evstudy.shtml. Accessed 6 February 2003.

Milunovich, S. \& Tsuei, A. 1996. 'EVA in the computer industry', Journal of Applied Corporate Finance, 9(1):104115.

Monteiro, A. 2006. 'A quick guide to financial ratios'. The Citizen, Moneyweb Business Insert, 6 May:3.

Muehlhauser, G.R. 1995. 'Putting performance measures to work', Journal of Applied Corporate Finance, 8(2):47-54.

O’Byrne, S.F. 1996. 'EVA and market value', Journal of Applied Corporate Finance, 9(1):116-125.

Rappaport, A. 1986. Creating shareholder value. New York: The Free Press.

Reimann, B.C. 1989. Managing for value: a guide to valuebased strategic management. Oxford: Basil Blackwell.

Stern, J. 1993. 'Value and people management', Corporate Finance, July:35-37.

Stewart III, G.B. 2003. 'How to fix accounting - measure and report economic profit', Journal of Applied Corporate Finance, 15(3):63-82.

Stowe, J.D., Robinson, T.R., Pinto, J.E. \& McLeavy, D.W. 2002. Analysis of equity investments: Valuation. Baltimore: AIMR.

Uyemura, D.G., Kantor, C.C. \& Pettit, J.M. 1996. 'EVA for banks: value creation, risk management, and profitability measurement', Journal of Applied Corporate Finance, 9(2):94-109. 


\section{APPENDIX A}

DU PONT ANALYSIS: STARTING WITH ROE

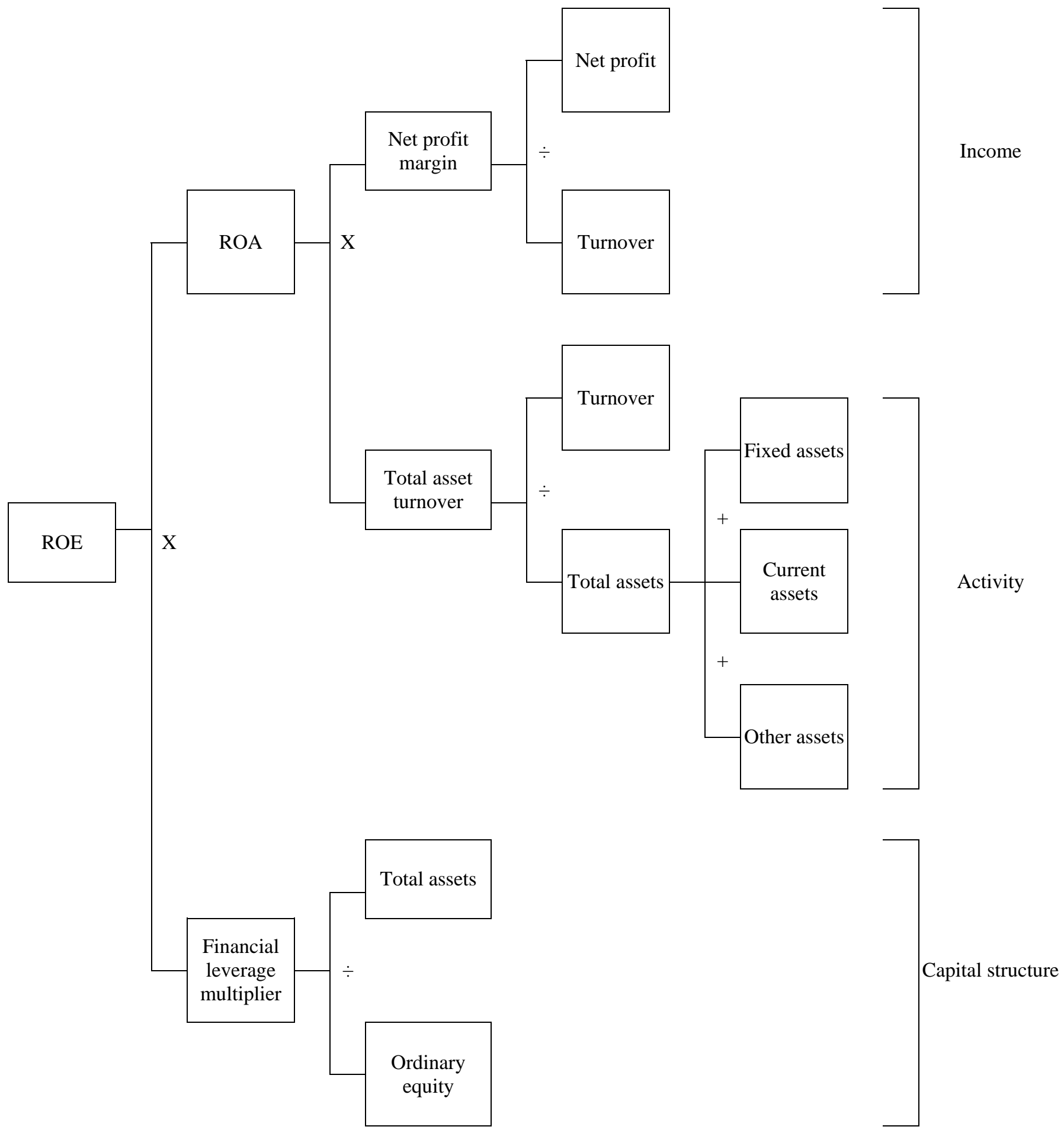

Source: Correia, Flynn, Uliana and Wormald (2003:5-20) 